\title{
Water management affects arsenic and cadmium accumulation in different rice cultivars
}

\author{
Pengjie Hu $\cdot$ Jiexue Huang $\cdot$ Younan Ouyang $\cdot$ Longhua Wu \\ Jing Song $\cdot$ Songfeng Wang $\cdot$ Zhu Li $\cdot$ Cunliang Han • \\ Liqiang Zhou $\cdot$ Yujuan Huang $\cdot$ Yongming Luo $\cdot$ Peter Christie
}

Received: 23 December 2012/ Accepted: 26 March 2013/Published online: 30 May 2013

(C) Springer Science+Business Media Dordrecht 2013

\begin{abstract}
Paddy rice (Oryza sativa L.) is a staple food and one of the major sources of dietary arsenic (As) and cadmium (Cd) in Asia. A field experiment was conducted to investigate the effects of four water management regimes (aerobic, intermittent irrigation, conventional irrigation and flooding) on $\mathrm{As}$ and $\mathrm{Cd}$ accumulation in seven major rice cultivars grown in Zhejiang province, east China. With increasing irrigation from aerobic to flooded conditions, the soil $\mathrm{HCl}$-extractable As concentrations increased significantly and the $\mathrm{HCl}$-extractable $\mathrm{Cd}$ concentrations decreased significantly. These trends were consistent with the As and Cd concentrations in the straw, husk and brown rice. Water management both before and after the full tillering stage affected $\mathrm{As}$ and $\mathrm{Cd}$
\end{abstract}

Electronic supplementary material The online version of this article (doi:10.1007/s10653-013-9533-z) contains supplementary material, which is available to authorized users.

P. Hu · J. Huang $\cdot$ L. Wu ( $₫) \cdot$ J. Song ·

S. Wang - Z. Li - C. Han - L. Zhou - Y. Huang

Key Laboratory of Soil Environment and Pollution

Remediation, Institute of Soil Science, Chinese

Academy of Sciences, Nanjing 210008, China

e-mail: lhwu@issas.ac.cn

Y. Ouyang

Chinese National Rice Research Institute,

Hangzhou 310006, China

Z. $\mathrm{Li}$

University of the Chinese Academy of Sciences, Beijing 100049, China accumulation in the grains. The intermittent and conventional treatments produced higher grain yields than the aerobic and flooded treatments. Cd concentrations in brown rice varied 13.1-40.8 times and As varied 1.75-8.80 times among the four water management regimes. Cd and As accumulation in brown rice varied among the rice cultivars, with Guodao 6 (GD6) was a low Cd but high-As-accumulating cultivar while Indonesia (IR) and Yongyou 9 (YY9) were low As but high-Cd-accumulating cultivars. Brown rice $\mathrm{Cd}$ and $\mathrm{As}$ concentrations in the 7 cultivars were significantly negatively correlated. The results indicate that $\mathrm{As}$ and $\mathrm{Cd}$ accumulated in rice grains with opposite trends that were influenced by both water management and rice cultivar. Production of 'safe' rice with respect to As and Cd might be possible by balancing water management and rice cultivar according to the severity of soil pollution.

\section{Y. Luo}

Key Laboratory of Coastal Zone Environmental

Processes, Yantai Institute of Coastal Zone Research, Chinese Academy of Sciences, Yantai 264003, China

P. Christie

Agri-Environment Branch, Agri-Food and Biosciences Institute, Newforge Lane, Belfast BT9 5PX, UK 
Keywords Arsenic - Bioavailability - Cadmium . Rice cultivars · Water management · Food security

\section{Introduction}

Arsenic (As) and cadmium (Cd) are two of the most toxic trace elements to plants and humans. Soil contamination by As and Cd occurs in many countries as a result of anthropogenic activities, particularly wastewater and solid waste disposal and intensive use of agrochemicals. Although As and Cd lack any essential function in plants, they can be taken up and accumulated in plants and subsequently enter the food chain to pose a risk to human health (Abedin et al. 2002; Verbruggen et al. 2009). Rice (Oryza sativa L.) is an important cereal crop second only to wheat worldwide. However, rice accumulates much higher concentrations of $\mathrm{As}$ and $\mathrm{Cd}$ in the shoots and grains compared with other cereals (wheat, barley and maize) (Williams et al. 2007), which makes rice contamination by As and $\mathrm{Cd}$ a global environmental health concern (Meharg and Rahman 2003; Tsukahara et al. 2003; Mondal and Polya 2008; Williams et al. 2009). There is an urgent need to develop strategies for reducing $\mathrm{As}$ and $\mathrm{Cd}$ uptake and to limit their translocation from roots to shoots or loading into the grains to minimize the health impacts of $\mathrm{As}$ and $\mathrm{Cd}$ from rice consumption.

Numerous studies have reported that water management affects Cd (Bingham et al. 1976; Kikuchi et al. 2008) and As (Xu et al. 2008; Li et al. 2009; Hua et al. 2011; Somenahally et al. 2011; Spanu et al. 2012) bioavailability in soils and their subsequent uptake by rice. When a paddy field is flooded and the soil has a low redox potential, any $\mathrm{Cd}$ present in the soil combines with sulphur (S) to form CdS which has a low solubility in water (Bingham et al. 1976). Thus, flooding during the growing season, especially during later stages of plant growth, can effectively reduce $\mathrm{Cd}$ concentrations in rice gains (Arao et al. 2009). In contrast, anaerobic conditions in paddy soil lead to the reduction in arsenate to arsenite which enhances the bioavailability of As to rice plants (Masscheleyn et al. 1991; Marin et al. 1993; Takahashi et al. 2004). Thus, growing rice aerobically results in a marked decline in As accumulation in the rice (Xu et al. 2008; $\mathrm{Li}$ et al. 2009). Unfortunately, $\mathrm{Cd}$ and $\mathrm{As}$ are often co-contaminants in agricultural soils. It is therefore necessary to investigate the feasibility of simultaneously mitigating both $\mathrm{As}$ and $\mathrm{Cd}$ accumulation in rice gains through water management.

Uptake of Cd and As has been shown to differ with rice cultivars (Morishita et al. 1987; Liu et al. 2005; Norton et al. 2009). Several studies have indicated that Cd uptake is significantly higher in Indica cultivars than in Japonica cultivars grown in Cd contaminated soils (He et al. 2006). Arsenic concentrations were found to be higher in hybrids than non-hybrids (Rahman et al. 2007; Dong et al. 2011). A high Cd translocation gene (qCdT7) has been identified in rice (Tezuka et al. 2010). Ahmed et al. (2011) reported that both genotype and environment influence As accumulation in rice grains. Therefore, selection and breeding of rice cultivars with low $\mathrm{As}$ and $\mathrm{Cd}$ accumulation have been considered to be reliable and achievable ways to reduce $\mathrm{As}$ and $\mathrm{Cd}$ in the rice grains in areas contaminated with both $\mathrm{Cd}$ and $\mathrm{As}$ (Zhang and Duan 2008).

In the present study, a field experiment was conducted to investigate the effects of four water management regimes on the accumulation of both As and $\mathrm{Cd}$ in seven major rice cultivars grown locally in Zhejiang province, east China. The main purpose was to achieve the optimum strategy for water management and local rice cultivar to alleviate $\mathrm{As}$ and $\mathrm{Cd}$ accumulation in the rice grains simultaneously and to achieve high yields.

\section{Materials and methods}

Site description and soil properties

The experimental site was located in a conventional agricultural field near Hangzhou city, Zhejiang province, east China. The soil belongs to the Typic Feleach-Stagnic Anthrosols (Gong 2007). The climate of the study area is moist monsoon with an annual precipitation of approximately $1,425 \mathrm{~mm}$ with the maximum during May and June and a mean temperature of $16{ }^{\circ} \mathrm{C}$. Agriculture is the principal land use with a typical rotation system of rice from summer to autumn and wheat or rape from winter to the following spring. Soil $\mathrm{pH}$ (in $\mathrm{H}_{2} \mathrm{O}$ ) was 5.30, soil organic carbon content was $16.9 \mathrm{~g} \mathrm{~kg}^{-1}$ and the cation exchange capacity (CEC) was $13.5 \mathrm{cmol}(+) \mathrm{kg}^{-1}$. Soil total $\mathrm{N}$, $\mathrm{P}$ and $\mathrm{K}$ were $1.46,0.68$ and $10.2 \mathrm{~g} \mathrm{~kg}^{-1}$, respectively. 
Soil available N, P and $\mathrm{K}$ were 95.2, 26.6 and $66.0 \mathrm{mg} \mathrm{kg}^{-1}$, respectively. Soil total $\mathrm{Zn}, \mathrm{Cd}, \mathrm{Cu}$ and As were 147, 0.48, 26.0 and $6.49 \mathrm{mg} \mathrm{kg}^{-1}$, respectively. The experimental soil was slightly contaminated with $\mathrm{Cd}$ according to the Chinese Environmental Quality Standard for Soils GB 1995-15618 (State Environmental Protection Administration of China 1995).

\section{Field experiment}

Seven major rice cultivars grown in Zhejiang province were used comprising two conventional Indica cultivars (Zhongxiang 1 and Indonesia, abbr. ZX1 and IR), three hybrid Indica cultivars (Liangyou Peijiu, Zhongzheyou 1 and Guodao 6, abbr. LYPJ, ZZY1 and GD6, respectively), one conventional Japonica cultivar (Xiushui 09, abbr. XS09) and one hybrid Japonica cultivar (Yongyou 9, abbr. YY9). The seeds of the seven cultivars were sown on May 28, 2010, and the seedlings were transplanted on June 21, 2010 with a distance between seedlings of $25 \mathrm{~cm}$. All plots were flooded for 1 week after transplanting, and then, four water management regimes were applied. These were (1) aerobic, that is, the water was discharged to leave a water layer $\sim 5 \mathrm{~cm}$ deep in the narrow ditch around the plot (about $10 \mathrm{~cm}$ lower than the rice field) to maintain aerobic conditions in the plot; (2) intermittent, irrigated intermittently with discharge to leave a water layer $\sim 5 \mathrm{~cm}$ deep in the ditch around the plot; (3) conventional irrigation, kept flooded until the full tillering stage (August 16) followed by intermittent irrigation; (4) flooding, flooded throughout the rice growing season. A split plot design was used with water treatments in the main plots and plant cultivars in the sub-plots. There were three replicate plots of each treatment. Each plot was $24 \mathrm{~m}^{2}$ in area and had a one-metre-wide buffer strip. The total volumes of irrigation water used were $\sim 300$, $3,702,6,203$ and $8,704 \mathrm{~m}^{3} \mathrm{ha}^{-1}$ in the aerobic, intermittent, conventional and flooded treatments, respectively. Rainfall was recorded (Supplementary Fig. S1) using an automatic rainfall recording instrument (WatchDog 2900ET Weather Station, Spectrum Technologies, Plainfield, IL), and the total rainfall was calculated to be $4,743 \mathrm{~m}^{3} \mathrm{ha}^{-1}$. As a result, the total volumes of irrigation water and rainfall over the whole crop growth period were 5,043, 8,445, 10,946 and $13,447 \mathrm{~m}^{3} \mathrm{ha}^{-1}$ in the aerobic, intermittent, conventional and flooded treatments, respectively.
Other management details were the same for all treatments. Basal nutrients consisted of $375 \mathrm{~kg} \mathrm{ha}^{-1}$ mixed fertilizer (N: P: K 15: 6.5: 12) was applied 1 day before transplanting. The first topdressing with $120 \mathrm{~kg} \mathrm{ha}^{-1}$ of urea (containing $46 \% \mathrm{~N}$ ) was applied on July 1 (10 days after transplanting), and the second topdressing was applied on July 7, comprising $150 \mathrm{~kg} \mathrm{ha}^{-1}$ of urea, $150 \mathrm{~kg} \mathrm{ha}^{-1}$ of mixed fertilizer and $120 \mathrm{~kg} \mathrm{ha}^{-1}$ of $\mathrm{KCl}$ (equivalent to $52 \% \mathrm{~K}$ ). All plants were harvested on October 16, 2010.

Sample collection and analysis

Rice plant samples and their corresponding fresh soil samples from the top $15 \mathrm{~cm}$ of the soil profile were collected from each plot at harvest. All the plant and soil samples were placed in an ice cooler and taken to the laboratory within $4 \mathrm{~h}$. Soil properties were analysed by standard methods (Sparks et al. 1996). Soil total and available $\mathrm{N}$ were determined by Kjeldahl digestion and distillation. Soil total and available $\mathrm{P}$ were determined by digestion with $\mathrm{H}_{2} \mathrm{SO}_{4} / \mathrm{HClO}_{4}$ and extraction with $0.1 \mathrm{M} \mathrm{HCl}$, respectively. Solution P was analysed by the molybdenum blue method. Soil total and available K were determined by digestion with $\mathrm{HCl}-\mathrm{HNO}_{3}$ (4: 1, $\mathrm{v} / \mathrm{v})$ and extraction with $1 \mathrm{M} \mathrm{NH}_{4} \mathrm{OAc}$, respectively. Solution $\mathrm{K}$ was analysed by flame photometry (Model 6400-A, Shanghai Analytical Instrument Factory, Shanghai, China). Soil total cationic heavy metals were analysed by digestion of $0.25 \mathrm{~g}$ samples with $12 \mathrm{ml}$ $\mathrm{HCl}-\mathrm{HNO}_{3}$ (4: 1, v/v). Soil total As was determined by digestion of $0.25 \mathrm{~g}$ samples with $10 \mathrm{ml} \mathrm{HNO}_{3}$ and $2 \mathrm{ml}$ $\mathrm{H}_{2} \mathrm{SO}_{4}$. Soil available As and $\mathrm{Cd}$ were determined by extraction of about $14 \mathrm{~g}$ fresh soil sample with $46 \mathrm{ml}$ $0.1 \mathrm{M} \mathrm{HCl}$. The fresh soil water contents were measured simultaneously. Plant samples were dried at low temperature $\left(50{ }^{\circ} \mathrm{C}\right)$. Plant (straw, brown rice, husk) $\mathrm{Cd}$ was analysed by digestion of $0.5 \mathrm{~g}$ samples with a mixture of $6 \mathrm{ml} \mathrm{HNO}_{3}$ and $4 \mathrm{ml} \mathrm{HClO}_{4}$. Plant As was analysed by digestion of $0.2-0.3 \mathrm{~g}$ samples with $6 \mathrm{ml}$ $\mathrm{HNO}_{3}$ and $2 \mathrm{ml} \mathrm{H}_{2} \mathrm{O}_{2}$. Cationic heavy metals in solution were measured by flame atomic absorption spectrophotometry (Varian SpectrAA 220 FS, Varian, Palo Alto, CA) or by graphite furnace atomic absorption spectrophotometry (Varian SpectrAA 220Z, Varian, Palo Alto, CA). Arsenic in solution was measured by atomic fluorescence spectrometry (AFS-930, Beijing Jitian Instruments, China). Certified reference materials GBW07401 and GBW07603 (Institute of Geophysical 
and Geochemical Exploration, Langfang, Hebei province, China) were used for quality control. All chemicals used were of analytical reagent grade, and the element concentrations measured in the reference materials were within the certified ranges. The soil N, P, K and total Cd and As results presented are based on air-dried soil weight, and soil available $\mathrm{As}$ and $\mathrm{Cd}$ results are based on oven-dried soil weight.

\section{Statistical analysis}

Statistical analysis was performed using the SPSS version 16.0 for Windows software package (SPSS Inc., Chicago, IL). Means were compared by analysis of variance (ANOVA) and Duncan's multiple range test at the $5 \%$ level. Data are presented as mean \pm standard error (SE) $(n=3)$. The correlation between $\mathrm{As}$ and $\mathrm{Cd}$ in tissues was examined using Pearson's test at the 5 and $1 \%$ levels of significance.

\section{Results}

\section{Soil HCl-extractable As and Cd concentrations}

The bioavailability of $\mathrm{As}$ and $\mathrm{Cd}$ in soils was determined by extraction with $0.1 \mathrm{M} \mathrm{HCl}$ at harvest (Table 1). Flooding and conventional irrigation had higher concentrations of $\mathrm{HCl}$-extractable As but lower $\mathrm{HCl}$-extractable $\mathrm{Cd}$ than aerobic and intermittent irrigation. The $\mathrm{HCl}$-extractable As concentrations in soil varied 2.45-6.46 times, and Cd concentrations varied 1.28-2.31 times among the various water regimes. It should be noted that at harvest, the intermittent treatment had low water content in the soil, but the conventional treatment retained a higher soil water content. Therefore, the $\mathrm{HCl}$-extractable metals showed no significant difference between intermittent and aerobic treatments or between conventional and flooded treatments.

\section{Plant As concentrations}

Figures 1 and 2 show the plant As and Cd concentrations. The As concentrations in the straw, husk and brown rice were affected by the various water treatments (Fig. 1). Generally, As concentrations followed the order aerobic $<$ intermittent $<$ conventional $<$ flooding. The aerobic treatment significantly decreased plant As accumulation compared to the flooded treatment. The order of As concentrations in different tissues was straw $>$ husk $>$ brown rice, regardless of water management or rice cultivar (Fig. 1). The variation in As concentration in straw was significantly greater than in brown rice. The straw As concentrations varied from 0.96 to $8.42 \mathrm{mg} \mathrm{kg}^{-1}$, and the brown rice As concentrations ranged from 0.14 to $0.45 \mathrm{mg} \mathrm{kg}^{-1}$. It was observed that in the aerobic treatment, the transfer factors of As, that is, the ratio of the concentration in brown rice to the concentration in straw, were higher than in the other water treatments for some cultivars such as ZX1, LYPJ, ZZY1, IR and GD6 (Fig. 3).

The As concentrations in rice tissues differed among the cultivars tested regardless of water

Table 1 Soil HCl-extractable As and Cd concentrations $\left(\mu \mathrm{g} \mathrm{kg}^{-1}\right)$

\begin{tabular}{llllllll}
\hline $\begin{array}{l}\text { Water } \\
\text { management }\end{array}$ & ZX1 & IR & LYPJ & ZZY1 & GD6 & XS09 & YY9 \\
\hline As & & & & & & \\
Aerobic & $23.9 \pm 5.6 \mathrm{~b}$ & $28.0 \pm 21.8 \mathrm{c}$ & $22.7 \pm 3.4 \mathrm{~b}$ & $26.4 \pm 1.6 \mathrm{~b}$ & $31.4 \pm 3.0 \mathrm{~b}$ & $22.3 \pm 0.7 \mathrm{~b}$ & $48.9 \pm 9.9 \mathrm{c}$ \\
Intermittent & $23.6 \pm 3.6 \mathrm{~b}$ & $31.4 \pm 17.4 \mathrm{c}$ & $29.5 \pm 7.2 \mathrm{~b}$ & $30.4 \pm 7.7 \mathrm{~b}$ & $36.8 \pm 18.4 \mathrm{~b}$ & $28.5 \pm 6.0 \mathrm{~b}$ & $34.9 \pm 9.7 \mathrm{c}$ \\
Conventional & $89.9 \pm 40.4 \mathrm{a}$ & $80.0 \pm 17.9 \mathrm{~b}$ & $58.9 \pm 16.7 \mathrm{ab}$ & $41.1 \pm 7.3 \mathrm{~b}$ & $79.8 \pm 26.7 \mathrm{a}$ & $137 \pm 4 \mathrm{a}$ & $113 \pm 22 \mathrm{~b}$ \\
Flooding & $111 \pm 18 \mathrm{a}$ & $125 \pm 19 \mathrm{a}$ & $90.4 \pm 30.9 \mathrm{a}$ & $64.6 \pm 24.9 \mathrm{a}$ & $110 \pm 21 \mathrm{a}$ & $144 \pm 30 \mathrm{a}$ & $153 \pm 25 \mathrm{a}$ \\
Cd & & & & & & & \\
Aerobic & $272 \pm 13 \mathrm{a}$ & $304 \pm 32 \mathrm{a}$ & $284 \pm 17 \mathrm{a}$ & $343 \pm 45 \mathrm{a}$ & $230 \pm 72 \mathrm{ab}$ & $322 \pm 22 \mathrm{a}$ & $298 \pm 34 \mathrm{a}$ \\
Intermittent & $316 \pm 39 \mathrm{a}$ & $280 \pm 36 \mathrm{a}$ & $286 \pm 10 \mathrm{a}$ & $359 \pm 26 \mathrm{a}$ & $301 \pm 69 \mathrm{a}$ & $337 \pm 35 \mathrm{a}$ & $277 \pm 20 \mathrm{a}$ \\
Conventional & $173 \pm 22 \mathrm{~b}$ & $123 \pm 88 \mathrm{~b}$ & $252 \pm 27 \mathrm{a}$ & $240 \pm 45 \mathrm{~b}$ & $240 \pm 19 \mathrm{ab}$ & $176 \pm 101 \mathrm{~b}$ & $42 \pm 11 \mathrm{~b}$ \\
Flooding & $169 \pm 73 \mathrm{~b}$ & $139 \pm 101 \mathrm{~b}$ & $221 \pm 72 \mathrm{a}$ & $167 \pm 44 \mathrm{~b}$ & $130 \pm 60 \mathrm{~b}$ & $162 \pm 67 \mathrm{~b}$ & $33 \pm 0 \mathrm{~b}$ \\
\hline
\end{tabular}

Data are mean values $\pm \mathrm{SE}(n=3)$. Data with the same letter in the same column and same metal indicate no significant difference at the $5 \%$ level 

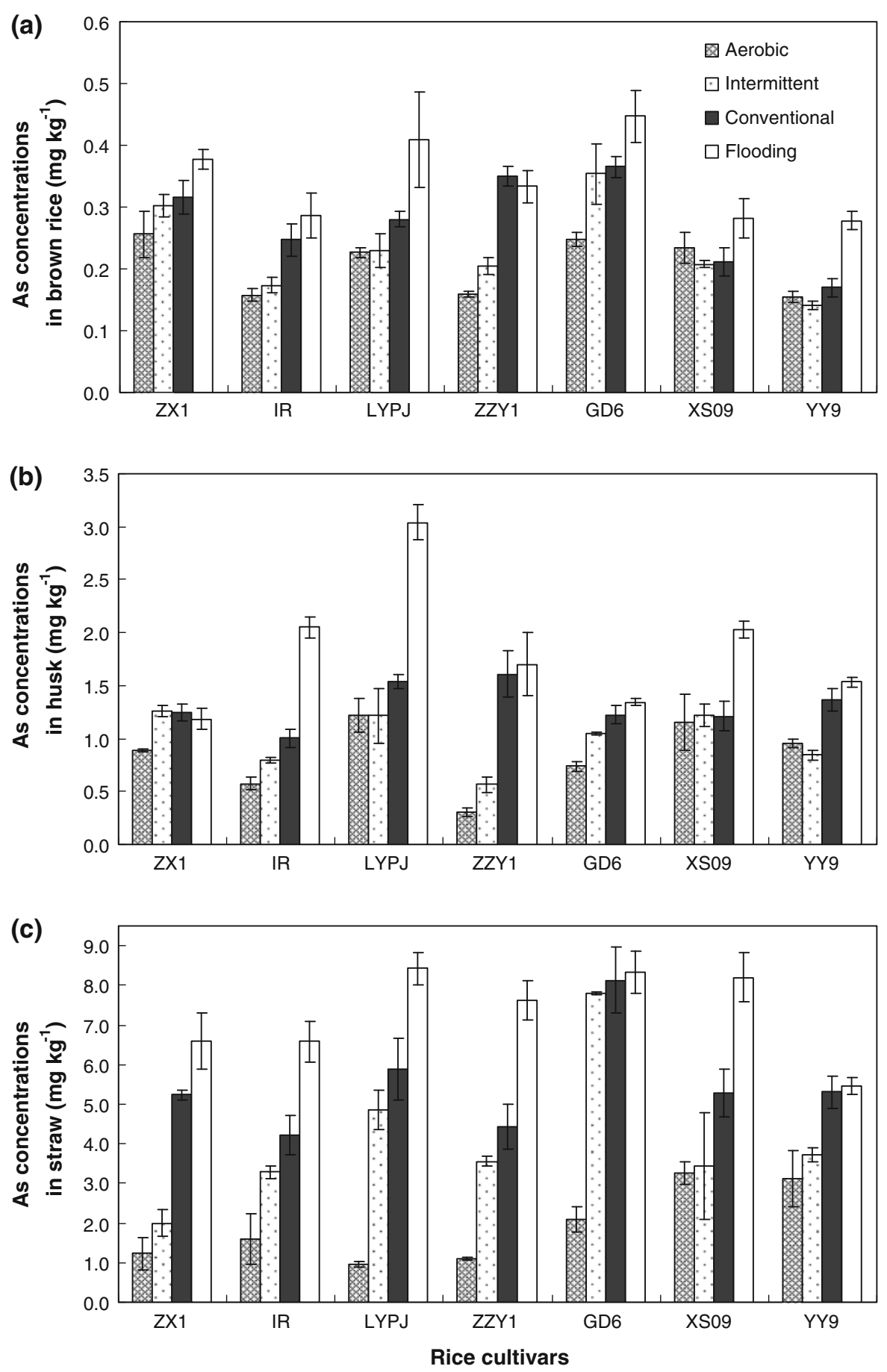

Fig. 1 Effects of water management regimes on As concentrations in the brown rice (a), husk (b) and straw (c) of different rice cultivars. The plotted columns are mean values $\pm \operatorname{SE}(n=3)$

treatments (Fig. 1). In straw, GD6 had relatively high As concentrations in the intermittent and conventional treatments and ZX1, LYPJ and ZZY1 had relatively low As concentrations in the aerobic treatment. GD6 had the highest brown rice total As concentrations, and IR and YY9 had the lowest As 

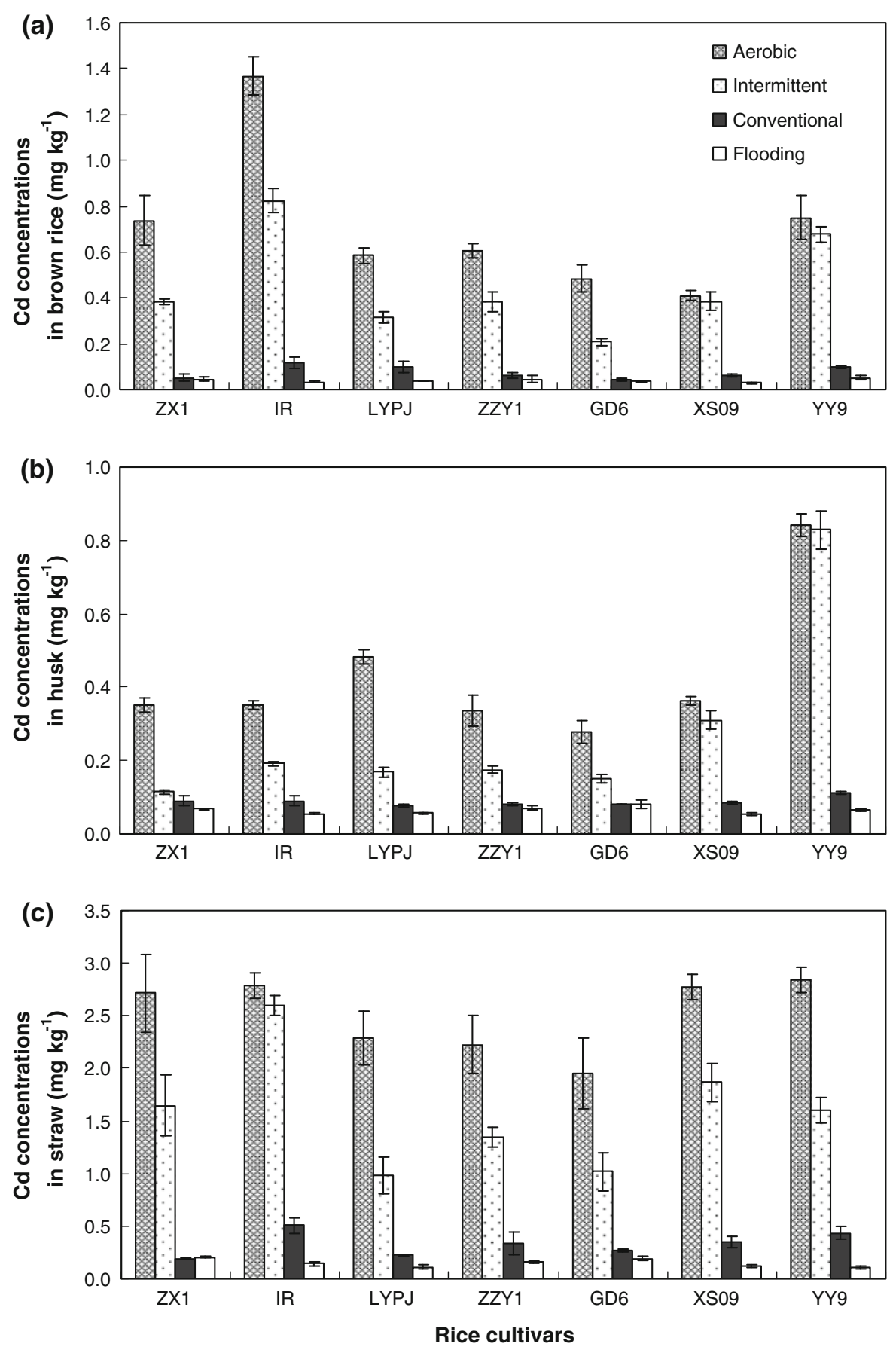

Fig. 2 Effects of water management regimes on Cd concentrations in the brown rice (a), husk (b) and straw (c) of different rice cultivars. The plotted columns are mean values $\pm \operatorname{SE}(n=3)$

concentrations regardless of water treatments. In the aerobic treatment, the As concentrations in brown rice of GD6 were 1.60 times higher than in YY9.

\section{Plant Cd concentrations}

Plant Cd concentrations were also largely affected by the different water treatments (Fig. 2). The order of 

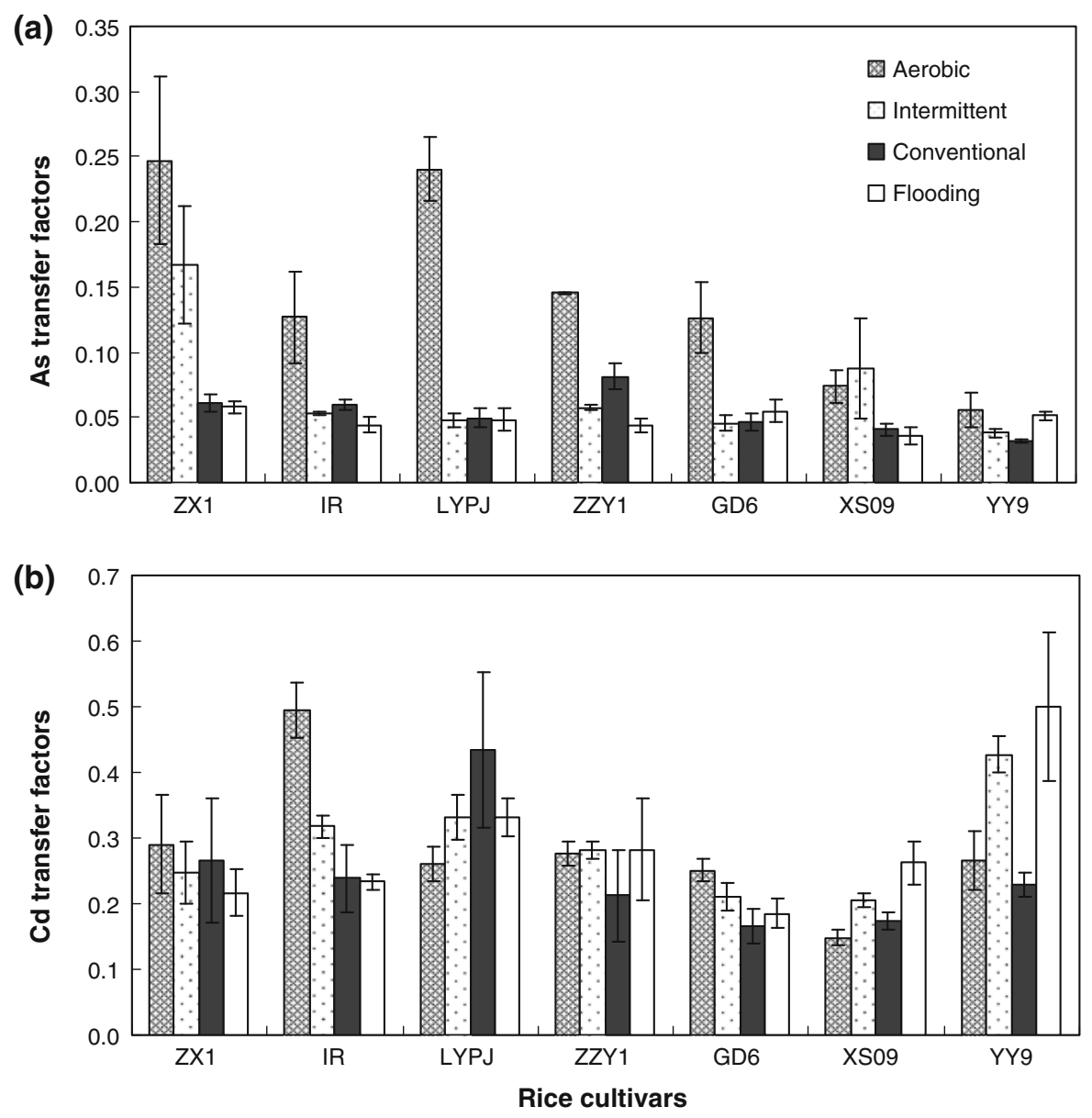

Fig. 3 Effects of water management regimes on transfer factors of $\mathrm{As}(\mathbf{a})$ and $\mathrm{Cd}(\mathbf{b})$ in different rice cultivars. The plotted columns are mean values $\pm \mathrm{SE}(n=3)$

total $\mathrm{Cd}$ concentrations among the four water management scenarios was aerobic $>$ intermittent $>$ conventional $>$ flooding. The continuously flooded and conventional treatments greatly decreased the $\mathrm{Cd}$ concentrations in straw, husk and brown rice compared to the aerobic and intermittent treatments. For example, in IR, the brown rice $\mathrm{Cd}$ in the flooded treatment was 40.8 times lower than in the aerobic treatment. According to the Maximum Levels of Contaminants in Foods of China (GB 2762-2005) [Ministry of Health of China and Standardization Administration of China (2005)], Cd concentrations in milled rice should be $<0.2 \mathrm{mg} \mathrm{kg}^{-1}$. The Cd concentrations in the brown rice of all 7 cultivars tested in the flooded treatment and conventional irrigation ranged from 0.03 to $0.12 \mathrm{mg} \mathrm{kg}^{-1}$ which was below the maximum Chinese level of $0.2 \mathrm{mg} \mathrm{kg}^{-1}$. Although the intermittent treatment decreased plant $\mathrm{Cd}$ accumulation compared to the aerobic treatment, $\mathrm{Cd}$ concentrations in the brown rice of the 7 cultivars still exceeded the maximum Chinese level.

In addition to water management, plant cultivars influence the plant $\mathrm{Cd}$ concentrations (Fig. 2). In the flooded treatment, $\mathrm{Cd}$ concentrations in the brown rice were very low $\left(0.03-0.05 \mathrm{mg} \mathrm{kg}^{-1}\right)$ and did not differ significantly among the cultivars. The $\mathrm{Cd}$ concentrations in the brown rice of IR under the aerobic and intermittent treatments reached 1.37 and $0.82 \mathrm{mg} \mathrm{kg}^{-1}$ which were notably higher than the other cultivars. Nevertheless, some cultivars such as XS09 and GD6 showed relatively low $\mathrm{Cd}$ accumulation in the brown rice, although they exceeded the maximum level of $0.2 \mathrm{mg} \mathrm{kg}^{-1}$ in the aerobic and intermittent treatments. Similar to brown rice, straw Cd in IR was the highest but 
Fig. 4 Correlation analysis of brown rice $\mathrm{As}$ and $\mathrm{Cd}$ concentrations among different rice cultivars in aerobic (a), intermittent (b), conventional (c) and flooded (d) treatments
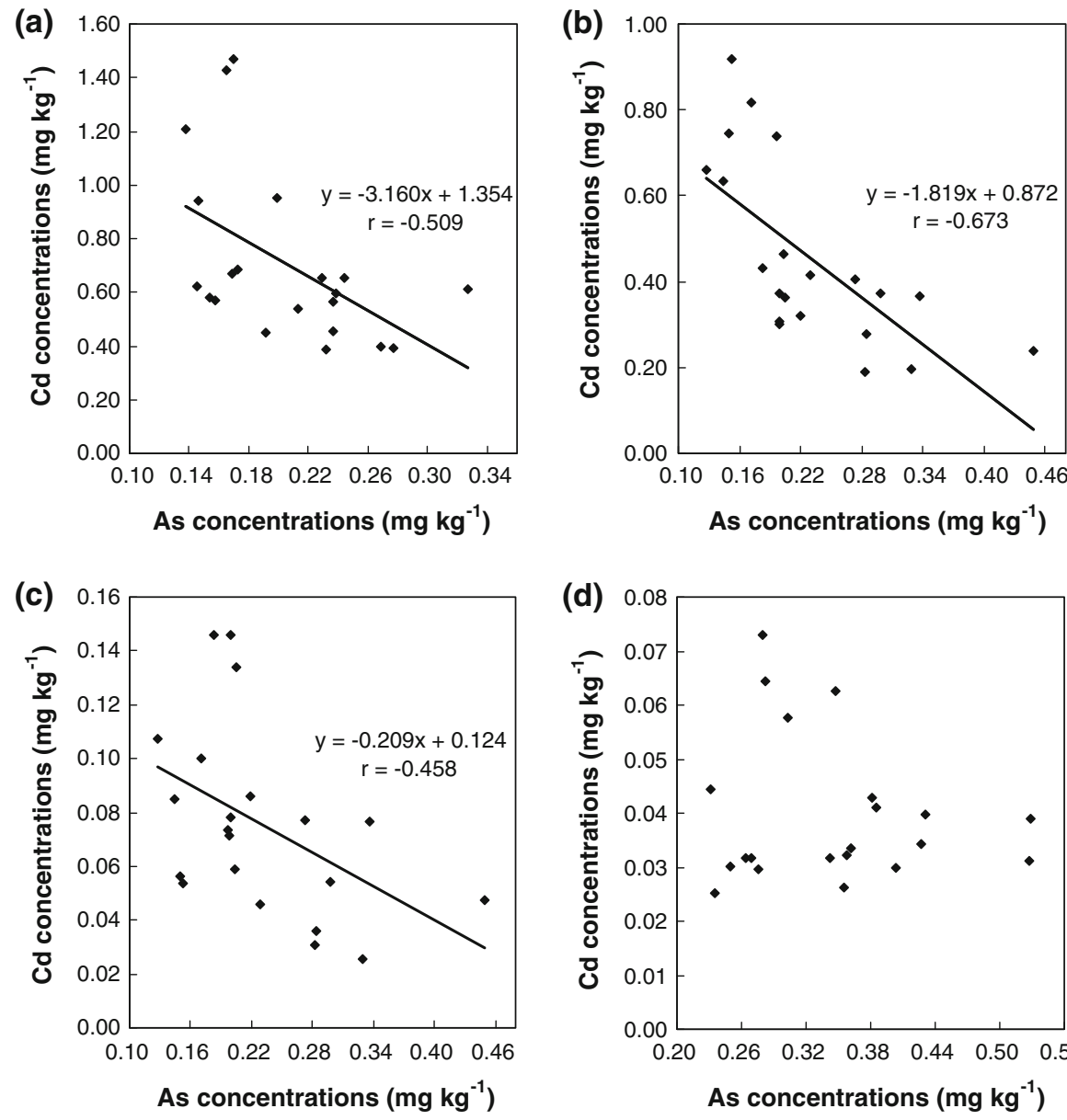

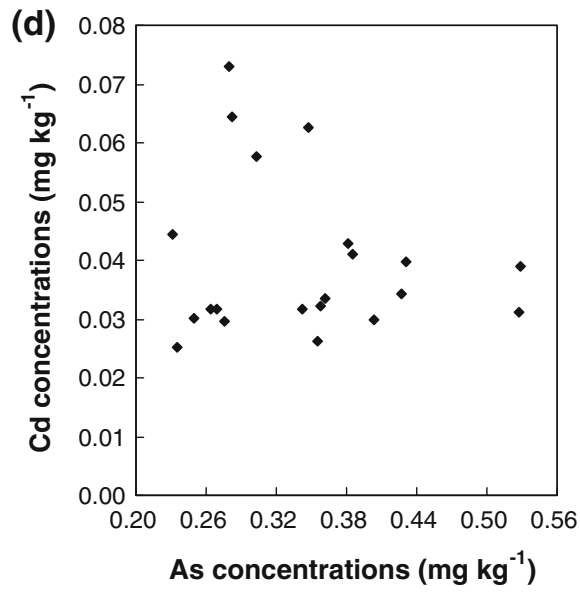

in GD6 was the lowest among the 7 cultivars. The transfer factors of Cd in XS09 and GD6 were lower than in the other cultivars regardless of water management (Fig. 3). Moreover, Pearson correlation analysis showed that the concentrations of $\mathrm{As}$ and $\mathrm{Cd}$ in the brown rice of all 7 rice cultivars were significantly negatively correlated in the aerobic $(r=-0.509$, $p<0.05)$, intermittent $(r=-0.673, p<0.01)$ and conventional $(r=-0.458, \quad p<0.05) \quad$ treatments (Fig. 4).

\section{Rice yields}

In all of the rice cultivars examined, the grain yields in the intermittent and conventional treatments were higher than in the aerobic and flooded treatments (Table 2). The super hybrid rice cultivar GD6 produced the highest grain yields. ZX1, a scented rice cultivar, gave lower yields. The local conventional irrigation method was most suitable for the pattern of crop growth.

\section{Discussion}

In the present study, we investigated the effects of four different water management regimes on the $\mathrm{As}$ and $\mathrm{Cd}$ accumulation and yields of 7 rice cultivars under field conditions. It is known that the water regime affects heavy metal speciation in soils and consequently the plant availability. Compared to aerobic conditions, anaerobic conditions increase the mobilization of As in soils. This is due to the reduction in arsenate to arsenite which then desorbs from the adsorption surfaces of iron oxyhydroxides into the solution phase, and due to the reductive dissolution of iron oxyhydroxides which releases the adsorbed or co-precipitated As into the solution (Takahashi et al. 2004; Xu 
Table 2 Rice grain yield of different cultivars (tonnes ha ${ }^{-1}$ )

\begin{tabular}{llllllll}
\hline $\begin{array}{l}\text { Water } \\
\text { management }\end{array}$ & ZX1 & IR & LYPJ & ZZY1 & GD6 & XS09 & YY9 \\
\hline Aerobic & $7.74 \pm 0.35 \mathrm{~b}$ & $6.44 \pm 0.45 \mathrm{~b}$ & $11.5 \pm 0.6 \mathrm{ab}$ & $8.41 \pm 0.60 \mathrm{c}$ & $12.4 \pm 0.5 \mathrm{a}$ & $7.84 \pm 0.61 \mathrm{~b}$ & $10.0 \pm 0.8 \mathrm{a}$ \\
Intermittent & $9.95 \pm 0.44 \mathrm{a}$ & $9.42 \pm 0.69 \mathrm{a}$ & $12.8 \pm 0.7 \mathrm{a}$ & $11.0 \pm 0.7 \mathrm{a}$ & $13.0 \pm 0.6 \mathrm{a}$ & $10.5 \pm 0.7 \mathrm{a}$ & $11.0 \pm 0.8 \mathrm{a}$ \\
Conventional & $10.0 \pm 0.5 \mathrm{a}$ & $9.25 \pm 0.47 \mathrm{a}$ & $12.9 \pm 0.7 \mathrm{a}$ & $10.8 \pm 0.5 \mathrm{a}$ & $13.1 \pm 0.5 \mathrm{a}$ & $10.2 \pm 0.7 \mathrm{a}$ & $10.9 \pm 0.7 \mathrm{a}$ \\
Flooding & $7.89 \pm 0.40 \mathrm{~b}$ & $7.25 \pm 0.44 \mathrm{~b}$ & $11.1 \pm 0.6 \mathrm{~b}$ & $9.32 \pm 0.67 \mathrm{~b}$ & $11.4 \pm 0.5 \mathrm{~b}$ & $8.00 \pm 0.58 \mathrm{~b}$ & $9.79 \pm 0.88 \mathrm{a}$ \\
\hline
\end{tabular}

Data are mean values $\pm \operatorname{SE}(n=3)$. Data with the same letter in the same column indicate no significant difference at the $5 \%$ level

et al. 2008; Yamaguchi et al. 2011). However, anaerobic conditions decrease the mobilization of $\mathrm{Cd}$ in soils due to the combining of $\mathrm{Cd}$ with sulphur $(\mathrm{S})$ to form CdS at low redox potential (Bingham et al. 1976). In the present study, the water treatments exerted opposite effects on As and Cd availability in the soil (Table 1). HCl-extractable As concentrations in the flooded treatment were 2.45-6.46 times higher than in the aerobic treatment. $\mathrm{HCl}$-extractable $\mathrm{Cd}$ concentrations in the flooded treatment were 1.28-2.31 times lower than in aerobic conditions. The effects of the intermittent and conventional treatments were intermediate between the aerobic and flooded treatments. Similarly, Xu et al. (2008) reported that during the period of active rice growth, the As concentration in the soil solution was 4-13 times higher under flooded than under aerobic conditions. Arao et al. (2009) also reported that $\mathrm{Cd}$ concentrations in the soil solution were below the detection limit during the time of flooding but increased during aerobic conditions.

Consistent with As and Cd bioavailability in soils, water management regimes exerted marked but opposite effects on $\mathrm{Cd}$ and As accumulation in the straw, husk and grains of the plants (Figs. 1,2). The increasing amount of water during the growing season from aerobic to flooded treatments significantly decreased plant $\mathrm{Cd}$ accumulation but increased As accumulation. In the conventional treatment, flooding was changed to intermittent irrigation after the full tillering stage in order to decrease non-effective tillering (Hu and Ding 2008). Compared to the continuously flooded treatment, intermittent irrigation after full tillering in the conventional treatment decreased As concentrations but increased Cd accumulation in the grain. Compared to the intermittent treatment, the conventional treatment with flooding before full tillering increased As concentrations but decreased $\mathrm{Cd}$ concentrations in the grains. This indicates that water management both before and after full tillering affected $\mathrm{As}$ and $\mathrm{Cd}$ accumulation in the grains. Similarly, in pot experiments, it has been reported that flooding 3 weeks before and after heading was most effective in reducing $\mathrm{Cd}$ concentrations in rice grains, while aerobic treatment for 3 weeks before and after heading effectively reduced As concentrations in the grains (Arao et al. 2009). Maintaining aerobic conditions during either the vegetative or reproductive stage of rice growth also decreased As accumulation in straw and grains significantly compared with rice grown under flooded conditions ( $\mathrm{Li}$ et al. 2009). It is therefore difficult to simultaneously reduce $\mathrm{As}$ and $\mathrm{Cd}$ accumulation in rice by using water management alone in soils polluted with both As and Cd.

However, in the present field experiment, $\mathrm{Cd}$ concentrations in the brown rice and straw varied 13.1- to 40.8-fold and 10.0- to 20.2-fold, respectively, among the different water regimes, but the As concentrations in the straw and in brown rice varied 1.75- to 8.80-fold and 1.21- to 2.08-fold, respectively. Clearly, the response of plant $\mathrm{Cd}$ concentrations was more sensitive than As concentrations to water management. Compared to aerobic and intermittent irrigation, flooding and conventional irrigation significantly decreased $\mathrm{Cd}$ concentrations in the straw, husk and grains. $\mathrm{Cd}$ concentrations in the brown rice of conventional irrigation were 6- to 15 -fold and 3- to 8 -fold lower than in aerobic conditions and intermittent irrigation, respectively. Cd concentrations in the brown rice of all 7 cultivars in flooding and conventional irrigation were well below the Chinese maximum levels (milled rice $\mathrm{Cd}<0.2 \mathrm{mg} \mathrm{kg}^{-1}$ ) (GB 2762-2005). This indicates that if we consider $\mathrm{Cd}$ only, flooding and conventional irrigation methods can ensure the production of $\mathrm{Cd}$ safe rice regardless of 
cultivar even in soil slightly polluted with $\mathrm{Cd}$ $\left(0.48 \mathrm{mg} \mathrm{kg}^{-1}\right)$. However, in the case of As, flooding and conventional treatments produced higher concentrations in the plants compared to the aerobic and intermittent treatments (Fig. 1). On the other hand, our field study demonstrates that water regime significantly affects rice yields. The local conventional irrigation method and intermediate method were the most consistent with the pattern of crop growth, whereas continuous flooding and aerobic conditions were unsuitable for rice growth (Table 2). Thus, if we take both $\mathrm{As}$ and $\mathrm{Cd}$ as well as grain yields into account, conventional irrigation is the most efficient choice to control both metals in rice grain in the present soil conditions. In addition, it has been observed that for some cultivars, the transfer factors of As in aerobic conditions are higher than in other water treatments (Fig. 3), possibly due to a reduction in As uptake by the roots and/or changes in As species in the tissues affecting As translocation (Raab et al. 2007; Norton et al. 2010).

There have been reports that different rice cultivars show different behaviours in relation to the uptake and accumulation of Cd (Morishita et al. 1987; He et al. 2006; Yu et al. 2006) and As (Rahman et al. 2007; Norton et al. 2009; Pillai et al. 2010; Ahmed et al. 2011; Dong et al. 2011). However, few reports have considered As and $\mathrm{Cd}$ accumulation simultaneously in rice cultivars. In the present study, the brown rice $\mathrm{Cd}$ concentrations in the flooded treatment were very low (0.03-0.05 mg kg-1) and did not differ significantly among the 7 cultivars (Fig. 1). In the other three water treatments, the brown rice $\mathrm{Cd}$ concentrations in IR (conventional Indica) and YY9 (hybrid Japonica) were the highest. Cd concentrations in these two cultivars were 2.68- to 3.95-fold higher and 1.55- to 3.25-fold higher than the lowest GD6 (three-line hybrid Indica). Conversely, regardless of water management, the As concentration in the brown rice of GD6 was the highest, but the As concentration in the brown rice in IR and YY9 was the lowest among the 7 cultivars. Moreover, the concentrations of $\mathrm{As}$ and $\mathrm{Cd}$ in the brown rice of all 7 rice cultivars were significantly negatively correlated (Fig. 4). It seems that rice tends to accumulate either $\mathrm{Cd}$ or As. These results indicate that an antagonism might exist between As and $\mathrm{Cd}$ accumulation in rice grains (Sun et al. 2008). They also suggest that $\mathrm{Cd}$ and $\mathrm{As}$ should be considered together when screening rice cultivars for food safety.
Among the 7 cultivars used in the present study, YY9 had relatively low As concentrations in the brown rice as well as relatively low As transfer factors from straw to grains. Thus, YY9 can be considered to be a lowAs-accumulating cultivar with potential for growing in As polluted fields with relatively aerobic irrigation. In contrast, GD6 had low Cd concentrations in the brown rice as well as low $\mathrm{Cd}$ transfer factors and might be a low-Cd-accumulating cultivar for $\mathrm{Cd}$ polluted fields with relatively anaerobic conditions. XS09 had low As and $\mathrm{Cd}$ transfer factors and accumulated neither high $\mathrm{Cd}$ nor high As in the brown rice, so it might be suitable for use in As and Cd co-polluted soils with conventional irrigation.

\section{Conclusions}

In the present field study, we investigated the effects of different water management regimes on $\mathrm{As}$ and $\mathrm{Cd}$ accumulation and yields of 7 rice cultivars. The results suggest that water management and rice cultivar dramatically affected As and Cd concentrations in rice grain but in opposite directions. Selecting proper water management measures and rice cultivars according to the degree of heavy metal pollution in soils will benefit food security as well as high yields. The present study suggests that the optimum strategies are to choose a low-Cd-accumulating cultivar such as GD6 with local conventional irrigation practice in $\mathrm{Cd}$ polluted paddy fields, a low-As-accumulating cultivar such as YY9 or IR with intermittent irrigation in As polluted paddy fields and a low-Cd-/As-accumulating cultivar such as XS09 with intermittent irrigation in $\mathrm{Cd}$ and As co-polluted paddy fields.

Acknowledgments This work was jointly supported by the National Natural Science Foundation of China (Projects 40971250 and 40821140539) and the High Technology Research Development Program of the People's Republic of China (Project 2012AA06A204).

\section{References}

Abedin, M. J., Feldmann, J., \& Meharg, A. A. (2002). Uptake kinetics of arsenic species in rice plants. Plant Physiology, 128, 1120-1128.

Ahmed, Z. U., Panaullah, G. M., Gauch, H., McCouch, S. R., Tyagi, W., Kabir, M. S., et al. (2011). Genotype and 
environment effects on rice (Oryza sativa L.) grain arsenic concentration in Bangladesh. Plant and Soil, 338, 367-382.

Arao, T., Kawasaki, A., Baba, K., Mori, S., \& Matsumoto, S. (2009). Effects of water management on cadmium and arsenic accumulation and dimethylarsinic acid concentrations in Japanese rice. Environmental Science \& Technology, 43, 9361-9367.

Bingham, F. T., Page, A. L., Mahler, R. J., \& Ganje, T. J. (1976). Cadmium availability to rice in sludge-amended soil under flood and non-flood culture. Soil Science Society of America Journal, 40, 715-719.

Dong, F., Lu, Y., Wang, X. X., Yan, Q. Y., Zhang, L., \& Pan, Q. (2011). Characteristics of arsenic accumulation in different rice (Oryza sativa L.) cultivars and its influencing factors in south China. Journal of Agro-Environment Science, 30, 214-219. (in Chinese).

Gong, Z. T. (2007). Pedogenesis and soil taxonomy. Beijing, China: Science Press.

He, J. Y., Zhu, C., Ren, Y. F., Yan, Y. P., \& Jiang, D. (2006). Genotypic variation in grain cadmium concentration of lowland rice. Journal of Plant Nutrition and Soil ScienceZeitschrift Fur Pflanzenernahrung Und Bodenkunde, 169, 711-716.

Hu, L., \& Ding, Y. (2008). Crop culture. Beijing: Higher Education Press.

Hua, B., Yan, W. G., Wang, J. M., Deng, B. L., \& Yang, J. (2011). Arsenic accumulation in rice grains: Effects of cultivars and water management practices. Environmental Engineering Science, 28, 591-596.

Kikuchi, T., Okazaki, M., Kimura, S. D., Motobayashi, T., Baasansuren, J., Hattori, T., et al. (2008). Suppressive effects of magnesium oxide materials on cadmium uptake and accumulation into rice grains -II: Suppression of cadmium uptake and accumulation into rice grains due to application of magnesium oxide materials. Journal of Hazardous Materials, 154, 294-299.

Li, R. Y., Stroud, J. L., Ma, J. F., McGrath, S. P., \& Zhao, F. J. (2009). Mitigation of arsenic accumulation in rice with water management and silicon fertilization. Environmental Science \& Technology, 43, 3778-3783.

Liu, J. G., Zhu, Q. S., Zhang, Z. J., Xu, J. K., Yang, J. C., \& Wong, M. H. (2005). Variations in cadmium accumulation among rice cultivars and types and the selection of cultivars for reducing cadmium in the diet. Journal of the Science of Food and Agriculture, 85, 147-153.

Marin, A. R., Masscheleyn, P. H., \& Patrick, W. H. (1993). Soil redox-pH stability of arsenic species and its influence on arsenic uptake by rice. Plant and Soil, 152, 245-253.

Masscheleyn, P. H., Delaune, R. D., \& Patrick, W. H. (1991). Effect of redox potential and $\mathrm{pH}$ on arsenic speciation and solubility in a contaminated soil. Environmental Science \& Technology, 25, 1414-1419.

Meharg, A. A., \& Rahman, M. (2003). Arsenic contamination of Bangladesh paddy field soils: Implications for rice contribution to arsenic consumption. Environmental Science \& Technology, 37, 229-234.

Ministry of Health of China, \& Standardization Administration of China. (2005). Maximum levels of contaminants in foods of China (GB 2762-2005). Beijing: Standards Press of China.

Mondal, D., \& Polya, D. A. (2008). Rice is a major exposure route for arsenic in Chakdaha block, Nadia district, West
Bengal, India: A probabilistic risk assessment. Applied Geochemistry, 23, 2987-2998.

Morishita, T., Fumoto, N., Yoshizawa, T., \& Kagawa, K. (1987). Varietal differences in cadmium levels of rice grains of Japonica, Indica, Javanica, and hybrid varieties produced in the same plot of a field. Soil Science and Plant Nutrition, 33, 629-637.

Norton, G. J., Duan, G. L., Dasgupta, T., Islam, M. R., Lei, M., Zhu, Y. G., et al. (2009). Environmental and genetic control of arsenic accumulation and speciation in rice grain: Comparing a range of common cultivars grown in contaminated sites across Bangladesh, China, and India. Environmental Science \& Technology, 43, 8381-8386.

Norton, G. J., Islam, M. R., Duan, G. L., Lei, M., Zhu, Y. G., Deacon, C. M., et al. (2010). Arsenic shoot-grain relationships in field grown rice cultivars. Environmental Science \& Technology, 44, 1471-1477.

Pillai, T. R., Yan, W. G., Agrama, H. A., James, W. D., Ibrahim, A. M. H., McClung, A. M., et al. (2010). Total grainarsenic and arsenic-species concentrations in diverse rice cultivars under flooded conditions. Crop Science, 50, 2065-2075.

Raab, A., Williams, P. N., Meharg, A., \& Feldmann, J. (2007). Uptake and translocation of inorganic and methylated arsenic species by plants. Environmental Chemistry, 4, 197-203.

Rahman, M. A., Hasegawa, H., Rahman, M. M., Islam, M. N., Miah, M. A. M., \& Tasmin, A. (2007). Arsenic accumulation in rice (Oryza sativa L.) varieties of Bangladesh: A glass house study. Water, Air, \& Soil pollution, 185, 53-61.

Somenahally, A. C., Hollister, E. B., Yan, W. G., Gentry, T. J., \& Loeppert, R. H. (2011). Water management impacts on arsenic speciation and iron-reducing bacteria in contrasting rice-rhizosphere compartments. Environmental Science \& Technology, 45, 8328-8335.

Spanu, A., Daga, L., Orlandoni, A. M., \& Sanna, G. (2012). The role of irrigation techniques in arsenic bioaccumulation in rice (Oryza sativa L.). Environmental Science \& Technology, 46, 8333-8340.

Sparks, D. L., Page, A. L., Helmke, P. A., Loeppert, R. H., Soltanpour, P. N., Tabatabai, M. A., et al. (1996). Methods of soil analysis. Part 3-chemical methods. Madison, USA: Soil Science Society of America Inc.

State Environmental Protection Administration of China. (1995). Environmental quality standards for soils (GB15618-1995). Beijing: Standards Press of China.

Sun, Y. H., Li, Z. J., Guo, B., Chu, G. X., Wei, C. Z., \& Liang, Y. C. (2008). Arsenic mitigates cadmium toxicity in rice seedlings. Environmental and Experimental Botany, 64, 264-270.

Takahashi, Y., Minamikawa, R., Hattori, K. H., Kurishima, K., Kihou, N., \& Yuita, K. (2004). Arsenic behavior in paddy fields during the cycle of flooded and non-flooded periods. Environmental Science \& Technology, 38, 1038-1044.

Tezuka, K., Miyadate, H., Katou, K., Kodama, I., Matsumoto, S., Kawamoto, T., et al. (2010). A single recessive gene controls cadmium translocation in the cadmium hyper accumulating rice cultivar Cho-Ko-Koku. Theoretical and Applied Genetics, 120, 1175-1182.

Tsukahara, T., Ezaki, T., Moriguchi, J., Furuki, K., Shimbo, S., Matsuda-Inoguchi, N., et al. (2003). Rice as the most 
influential source of cadmium intake among general Japanese population. Science of the Total Environment, 305, 41-51.

Verbruggen, N., Hermans, C., \& Schat, H. (2009). Mechanisms to cope with arsenic or cadmium excess in plants. Current Opinion in Plant Biology, 12, 364-372.

Williams, P. N., Lei, M., Sun, G. X., Huang, Q., Lu, Y., Deacon, C., et al. (2009). Occurrence and partitioning of cadmium, arsenic and lead in mine impacted paddy rice: Hunan, China. Environmental Science \& Technology, 43, 637-642.

Williams, P. N., Villada, A., Deacon, C., Raab, A., Figuerola, J., Green, A. J., et al. (2007). Greatly enhanced arsenic shoot assimilation in rice leads to elevated grain levels compared to wheat and barley. Environmental Science \& Technology, $41,6854-6859$.
Xu, X. Y., McGrath, S. P., Meharg, A. A., \& Zhao, F. J. (2008). Growing rice aerobically markedly decreases arsenic accumulation. Environmental Science \& Technology, 42, 5574-5579.

Yamaguchi, N., Nakamura, T., Dong, D., Takahashi, Y., Amachi, S., \& Makino, T. (2011). Arsenic release from flooded paddy soils is influenced by speciation, $\mathrm{Eh}, \mathrm{pH}$, and iron dissolution. Chemosphere, 83, 925-932.

Yu, H., Wang, J. L., Fang, W., Yuan, J. G., \& Yang, Z. Y. (2006). Cadmium accumulation in different rice cultivars and screening for pollution-safe cultivars of rice. Science of the Total Environment, 370, 302-309.

Zhang, J., \& Duan, G. L. (2008). Genotypic difference in arsenic and cadmium accumulation by rice seedlings grown in hydroponics. Journal of Plant Nutrition, 31, 2168-2182. 